\title{
EXPERIMENTAL EVALUATION OF THE EFFECT OF WATER-CEMENT RATIO ON COMPRESSIVE, ABRASION STRENGTH, HYDRAULIC CONDUCTIVITY COEFFICIENT AND POROSITY OF NANO-SILICA CONCRETES
}

\author{
Verya Ghasemipor ${ }^{\text {a }}$, Saber Piroti ${ }^{\text {a* }}$ \\ ${ }^{a}$ Department of Civil Engineering, Mahabad Branch, Islamic Azad University, Mahabad, Iran, \\ E-mails: bardya257@gmail.com, * s.piroti@iau-mahabad.ac.ir
}

Received: 13.06.2018 / Accepted: 20.07.2018 / Revised: 20.11.2018 / Available online: 15.12.2018

DOI: $10.2478 /$ jaes-2018-0013

KEYWORDS: Abrasion Strength, Compressive Strength, Hydraulic Conductivity Coefficient, Porosity, Nano-Silica.

\begin{abstract}
:
Dams are considered as strategic structures due to their initial role in economic system of the country, therefore, they are expected to be fully functional and powerful. Nano technology could be an effective factor of abrasion and compressive strength, porosity and hydraulic conductivity coefficient of the concrete, thus more scientific research is essential to be carried out on these types of concrete due to their quite modern and high technology. In the current study, the effects of water-cement ratio on compressive and abrasion strength, porosity and hydraulic conductivity coefficient of concrete was investigated. The constructed concrete samples with $4 \%$ Nano-silica and water-cement ratios of 0.35 to 0.55 were tested. Other design features remained fixed in all concrete samples. The compressive strength of block samples of $150 \times 150 \times 150 \mathrm{~mm}$ were assessed in terms of time lasting 7,28 and 90 days. The abrasion strength of the identical block samples were tested after 28 days. The hydraulic conductivity coefficient of cylindrical shape samples with the diameter $150 \mathrm{~mm}$ and height of $300 \mathrm{~mm}$ were experimented after 28 days. The results of the experiments indicated that by reducing the water-cement ratio from 0.55 to 0.35 , the compressive strength increased $37.13,40.14$ and $38.22 \%$ for 7, 28 and 90 days age samples respectively and abrasion strength of concrete increased $38.22 \%$ and the hydraulic conductivity coefficient $(\mathrm{m} / \mathrm{s})$ and depth of penetration $(\mathrm{mm})$ of the concrete decreased from $27.76 \times 10^{-15}$ and 2.756 to $1.5 \times 10^{-15}$ and 0.784 respectively. In addition porosity decreased from 12.76 to $11.22 \%$.
\end{abstract}

\section{INTRODUCTION}

Yigiter et al. (2007) studied the effect of cement type, cement content and water-cement ratio on concrete resistance against sea water. The results showed that slag (blast furnace) cement mixtures have better mechanical characteristics and considerable higher resistance against chloride penetration of sea water in comparison with Portland cement mixtures. Concrete durability is directly related to permeability along with cement content, compaction and curing. Permeability is a function of pores inside. It is affected by the percentage of porosity, size distribution and the continuity of pores (Ahmad et al., 2005). Concrete strength, durability, and volume stability is greatly influenced by voids in the hydrated cement paste. Therefore, porosity, i.e., ratio of voids volume to total volume, greatly influences concrete properties. Also porosity is considered as durability index (Benavente et al., 2004) of building material. In RCC, deteriorating agents i.e. chloride ions, carbon dioxide penetrate to corrode steel through the pores (Ishida et al., 2007). So the lower its permeability, the greater is its potential for durability. The empty space (porosity) is influenced mainly by the water to cement ratio (Wong and Buenfeld, 2009). The physically bonded water exists in the spaces between hydrated cement crystals. Here, the permeability of the paste is important because the paste envelopes all constituents in the concrete. The main influential factor behind the formation of pores is the watercontent in the mixture. Therefore, paste permeability i.e. continuity of pores, is directly related to water-cement ratio

\footnotetext{
* Corresponding author: Saber PIROTI, e-mail: s.piroti@iau-mahabad.ac.ir
} 
and the degree of cement hydration or length of moistcuring. Longer curing times and lower water-cement ratios resulted in lower porosity values (Bentz and Stutzman, 2006). Kim et al. (2014) studied how water-cement ratio affects the durability as well as porosity of the cement mortar with constant cement amount. This investigation had the conclusion that the increase of w/c ratio from 0.45 to 0.60 results in the increase of water loss, porosity, chloride diffusion coefficient, air permeability, moisture sorptivity, and moisture diffusion coefficient etc. Considerable developments in concrete technology have been taken place in last quarter of the century. Compared to the past, to achieve sufficiently high strength levels at early ages, Blaine fineness and tricalcium silicate $\left(3 \mathrm{CaO}-\mathrm{SiO}_{2}\right)$ contents of cements were increased. Thus, same strength levels obtained with less cement or with higher water-cement (W/C) ratio results in an increase in the permeability of concrete. So, nowadays, many concrete structures built after 1970s, have been suffering because of durability problems (Shannag and Shaia, 2003). In the aggressive exposures, the concrete quality should be specified in terms of durability, in addition to workability and strength (Al-Amoudi et al., 2003). Prediction of service life and durability can only be made by characterization of both the material properties and the environment. Pollutants may be contributed by either the mix constituents or they may penetrate the hardened concrete from external environment. It is well known that pozzolanic materials improve the sulfate and sea water resistance of concrete (Baradan and Yazici, 2002), (Shannag and Shaia, 2003), (Lorenzo et al., 2003). Concrete remains the choice of engineers in construction materials owing to its remarkable features like mold-ability to various shapes, easily available ingredients, high strength and low cost in spite of its environmental concern. Approximately 20 billion metric ton of concrete is being produced every year (Mehta and Meryman, 2009). The production of cement for concrete is contributing nearly $8 \%$ of global carbon dioxide emission (Olivier et al., 2012) and thus, a matter of concern for environmentalist. It is a composite material with wide range of length scales from millimeter to nanometer. Usually concrete is taken as one material by considering its bulk strength and other engineering properties, but at micro and nanoscale, it is having different type of compositions with complex characteristics. There has been always a relationship between the microstructure and bulk properties and researchers are making efforts to establish this relationship in concrete. The contemporary building sector is working for the development of advanced and new cementitious materials. Performance enhancement of cementitious system consists of judicious utilization of materials, developing more durable and sustainable concrete to reduce the maintenance and life cycle cost (Ali, 2012).

Considering the effect of water-cement ratio on four mechanical characteristics of concrete (including compressive strength, abrasion resistance, hydraulic conductivity coefficient and porosity) and studying the behavior of concrete in a wide range have been the objectives of this research.

\section{EXPERIMENTS CONDUCTED ON CONCRETE SAMPLES}

\subsection{Mixture prepared for Nano-silica concrete}

In preparation of samples of Nano-silica concrete mixture, the following components were considered:

- The slump test range of specimens was 50 to $100 \mathrm{~mm}$ according to ASTM C 143-78 standard.

- The aggregates (gravel and sand) were ballast kind.

- The maximum diameter of aggregates was $12 \mathrm{~mm}$.

- The consuming cement was in regular Portland kind Type 1.

- The optimized Nano-silica content and $4 \%$ of cement's weight was replaced.

- The characteristic design strength has considered 45 MPa.

- The water-cement ratio varied and the ratio ranged and tested between 0.35 until 0.55 .

- GELENIUM was used as superplasticizer.

The results of chemical analysis of Nano-silica and Portland cement type 1 and the chemical and physical are reveals in Table 1. Figure 1 shows used Nano-silica in the construction of test samples.

Table 1. Chemical compositions of the used cement and

\begin{tabular}{|c|c|c|}
\hline $\begin{array}{c}\text { Cement } \\
\text { content } \\
(\%)\end{array}$ & $\begin{array}{c}\text { Nano-silica } \\
\text { content } \\
(\%)\end{array}$ & $\begin{array}{c}\text { Chemical } \\
\text { component }\end{array}$ \\
\hline 20 & 94.06 & $\mathrm{SiO}_{2}$ \\
\hline 6 & 0.13 & $\mathrm{AL}_{2} \mathrm{O}_{3}$ \\
\hline 3 & 0.037 & $\mathrm{Fe}_{2} \mathrm{O}_{3}$ \\
\hline 65 & 0.1 & $\mathrm{CaO}$ \\
\hline 2 & 0.09 & $\mathrm{MgO}$ \\
\hline 1 & 1.13 & $\mathrm{Na}_{2} \mathrm{O}$ \\
\hline 1 & 0.02 & $\mathrm{~K}_{2} \mathrm{O}$ \\
\hline 2 & 0.026 & $\mathrm{SO}_{3}$ \\
\hline
\end{tabular}

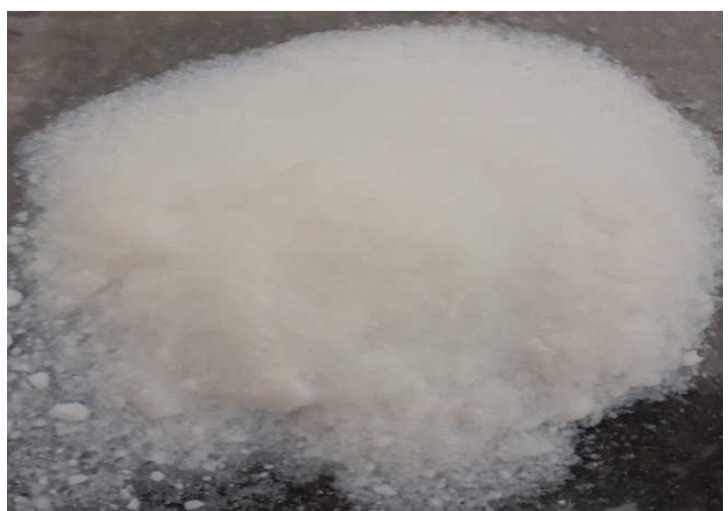

Figure 1. Nano-silica used for reinforcing concrete

The grading of aggregates (gravel and sand) and mixture design of Nano-silica concrete were according to ASTM C 
136 and ACI 211 standards respectively. The later one was done with weighting method and the results are shown in Table 2.

Table 2. Concrete mixture design proportions $\left(\mathrm{Kg} / \mathrm{m}^{3}\right)$

\begin{tabular}{|c|c|c|c|c|c|c|}
\hline W/C & Gravel & Sand & Cement & $\begin{array}{c}\text { Nano- } \\
\text { silica }\end{array}$ & Water & $\begin{array}{c}\text { Super } \\
\text { plasticizer } \\
(\%)\end{array}$ \\
\hline 0.35 & 870 & 790 & 480 & 20 & 175 & 8 \\
\hline 0.40 & 870 & 790 & 480 & 20 & 200 & 8 \\
\hline 0.45 & 870 & 790 & 480 & 20 & 225 & 8 \\
\hline 0.50 & 870 & 790 & 480 & 20 & 250 & 8 \\
\hline 0.55 & 870 & 790 & 480 & 20 & 275 & 8 \\
\hline
\end{tabular}

\subsection{Test methods}

The following tests have been done on concrete specimens in this research:

- The compressive strength of cubic samples of $150 \times 150 \times 150 \mathrm{~mm}$ after permanence of 7,28 and 90 days were determined according to BS 1881 part 116 standard. Figure 2 illustrates the apparatus of compressive strength measuring for concrete samples.

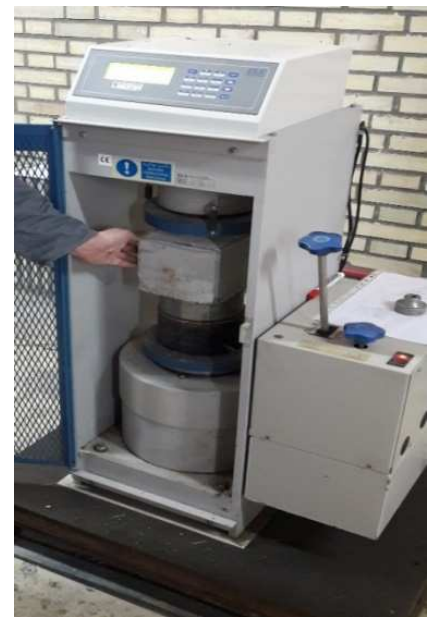

Figure 2. The compressive strength apparatus measuring

- The abrasion strength of cubic samples of $150 \times 150 \times 150$ $\mathrm{mm}$ after 28 days in water sand blast way were defined according to ASTM C 418 standard. The following equation was used for abrasion depth calculation:

$h_{e}=V / \mathrm{A}$

where: $\mathrm{h}_{\mathrm{e}}$ is the abrasion depth, $\mathrm{V}$ is the volume of holes and $\mathrm{A}$ is the area of triturated surface.

Figure 3 is the schematic of the apparatus of abrasion strength measuring in concrete samples.

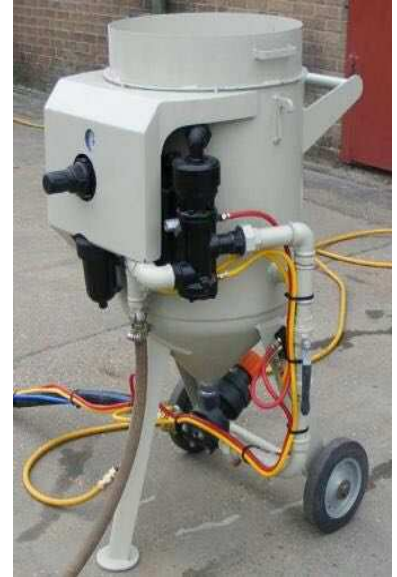

Figure 3. The apparatus of abrasion strength measuring

- The penetration method was used to determine the hydraulic conductivity coefficient of cylindrical shape samples with the diameter $150 \mathrm{~mm}$ and height of $300 \mathrm{~mm}$ after 28 days according to ISO 1920-5 standard. The following equations were used to calculate the hydraulic conductivity coefficient and porosity of specimens:

$K_{P}=h_{P}^{2} V / 2 T h$

where: $K_{p}$ is the permeability coefficient of concrete, $\mathrm{m} / \mathrm{s} ; \mathrm{h}_{\mathrm{p}}$ is water permeability depth, $\mathrm{m}$; $\mathrm{T}$ : water permeability time, sec; h: height arising from pressure, $\mathrm{m}$; V: concrete porosity and in the formula for porosity is given as follows:

$V=\{(\mathrm{w} / \mathrm{c}) \times(100-36.15 \times \alpha) /(\mathrm{w}+100 / \mathrm{g})\}$

where: $w / c$ is water-cement ratio; $\alpha$ is cement hydration degree; $\mathrm{w}$ is gravity water of concrete, $\mathrm{Kg} / \mathrm{m}^{3}$ and $\mathrm{g}$ is cement specific weight, $\mathrm{gr} / \mathrm{cm}^{3}$.

Figure 4 shows the apparatus of penetration depth of water and hydraulic conductivity coefficient measuring for concrete samples.

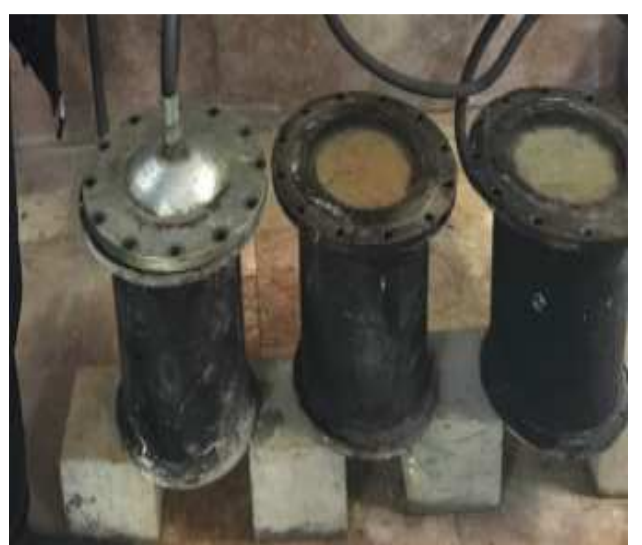

Figure 4. The apparatus of penetration depth of water 


\section{EXPERIMENTAL INVESTIGATION AND RESULTS}

\subsection{Compressive strength experiments}

After carrying out the compressive strength experiment, some outcomes were extracted and demonstrated in Tables 3-8:

Table 3. Compressive strength experiment for samples with water-cement ratio of 0.35

\begin{tabular}{|c|c|c|}
\hline $\begin{array}{c}\text { Compressive } \\
\text { strength (MPa) }\end{array}$ & Age, days & W/C \\
\hline 47.21 & 7 & \multirow{2}{*}{0.35} \\
\hline 63.35 & 28 & \\
\hline 67.14 & 90 & \\
\hline
\end{tabular}

Table 4. Compressive strength experiment for samples with water-cement ratio of 0.40

\begin{tabular}{|c|c|c|}
\hline $\begin{array}{c}\text { Compressive } \\
\text { strength (MPa) }\end{array}$ & Age, days & W/C \\
\hline 45.21 & 7 & \multirow{2}{*}{0.40} \\
\hline 59.16 & 28 & \\
\hline 64.30 & 90 & \\
\hline
\end{tabular}

Table 5. Compressive strength experiment for samples with water-cement ratio of 0.45

\begin{tabular}{|c|c|c|}
\hline $\begin{array}{c}\text { Compressive } \\
\text { strength (MPa) }\end{array}$ & Age, days & W/C \\
\hline 42.41 & 7 & \multirow{2}{*}{0.45} \\
\hline 55.32 & 28 & \\
\hline 60.25 & 90 & \\
\hline
\end{tabular}

Table 6. Compressive strength experiment for samples with water-cement ratio of 0.50

\begin{tabular}{|c|c|c|}
\hline $\begin{array}{c}\text { Compressive } \\
\text { strength (MPa) }\end{array}$ & Age, days & W/C \\
\hline 40.36 & 7 & \multirow{2}{*}{0.50} \\
\hline 52.23 & 28 & \\
\hline 56.42 & 90 & \\
\hline
\end{tabular}

Table 7. Compressive strength experiment for samples with water-cement ratio of 0.55

\begin{tabular}{|c|c|c|}
\hline $\begin{array}{c}\text { Compressive strength } \\
(\mathrm{MPa})\end{array}$ & Age, days & W/C \\
\hline 36.44 & 7 & \multirow{2}{*}{0.55} \\
\hline 47.12 & 28 & \\
\hline 51.33 & 90 & \\
\hline
\end{tabular}

Table 8. Increase compressive strength after age of 7, 28 and 90 days for various $\mathrm{W} / \mathrm{C}$

\begin{tabular}{|c|c|c|c|}
\hline $\begin{array}{c}\text { Increase of } \\
\text { compressive } \\
\text { strength after } \\
90 \text { days, } \%\end{array}$ & $\begin{array}{c}\text { Increase of } \\
\text { compressive } \\
\text { strength after } \\
28 \text { days, } \%\end{array}$ & $\begin{array}{c}\text { Increase of } \\
\text { compressive } \\
\text { strength after } \\
7 \text { days, \% }\end{array}$ & W/C \\
\hline 38.22 & 40.14 & 37.13 & 0.35 \\
\hline 30.15 & 33.18 & 30.11 & 0.40 \\
\hline 21.75 & 23.72 & 21.42 & 0.45 \\
\hline 14.62 & 15.34 & 15.33 & 0.50 \\
\hline
\end{tabular}

The highest compressive strength after 7,28 and 90 days was like the samples with water-cement ratio of 0.35 . The least or minimum compressive strength after 7,28 and 90 days was as the same of the strength of samples with watercement ratio of 0.55. By increasing the water-cement ratio, the compressive strength of concrete samples decreased daily. Regarding to the particular level of Nano-silica (140 $\mathrm{m}^{2} / \mathrm{g}$ ) and the necessity for ample water to obtain the desired fluidity, $4 \%$ is the most suitable amount, so that this amount of Nano-silica is optimum and its higher quantity have negative effects to fluidity and performance of concrete.

Figure 5 explains the variation of compressive strength in aspect of water-cement ratio for samples after a period of 7 , 28 and 90 days.

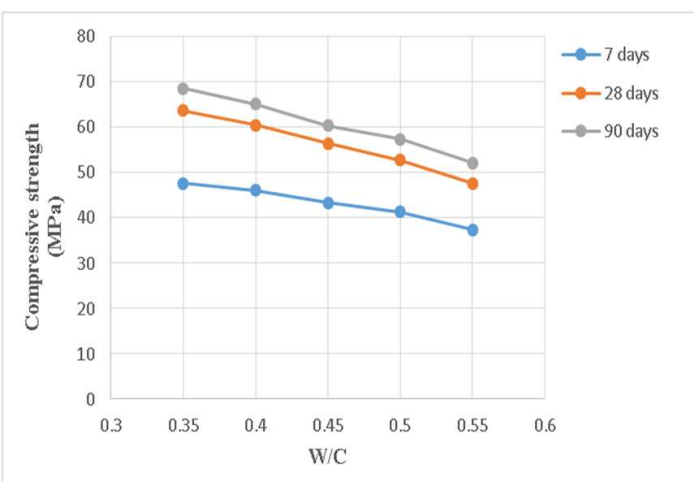

Figure 5. The variation curve of compressive strength of specimens at 7, 28 and 90 days with respect to watercement ratio

Figure 6 reveals the compressive strength increased while the reduction of water-cement ratio in Nano-silica concrete caused the compressive strength increase. By reduction of water-cement ratio from 0.55 to 0.35 after 7 days, compressive strength of concrete increased to $37.13 \%$. Also, by reduction of water-cement ratio from 0.55 to 0.35 after 28 days, compressive strength of concrete increased to $40.14 \%$. By reduction of water-cement ratio from 0.55 to 0.35 after 90 days, compressive strength of concrete increased to $38.22 \%$.

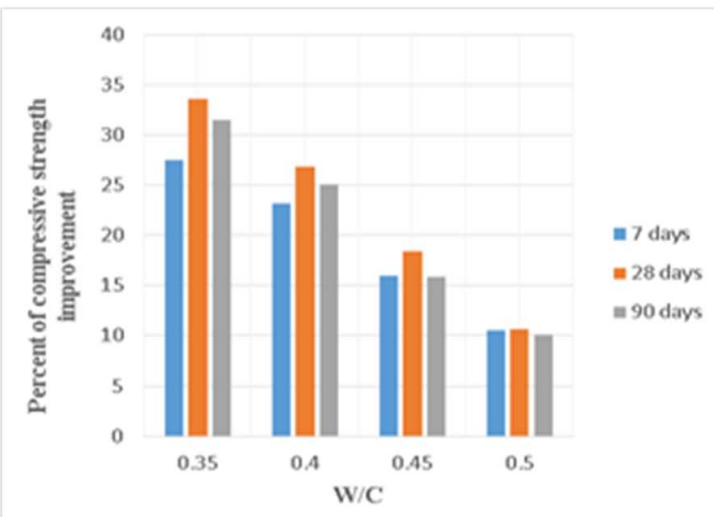

Figure 6. The chart of compressive strength improvement of specimens with respect to water-cement ratio at 7, 28 and 90 days 


\subsection{Abrasion strength experiments}

The abrasion strength experiments were conducted; the following results are summarized in Table 9 as stated as follows:

Table 9. Abrasion depth according to water-cement ratio

\begin{tabular}{|c|c|c|c|c|c|}
\hline W/C & 0.35 & 0.40 & 0.45 & 0.50 & 0.55 \\
\hline $\begin{array}{c}\text { Abrasion } \\
\text { depth, } \\
(\mathrm{mm})\end{array}$ & 6.21 & 7.52 & 9.52 & 10.21 & 11.05 \\
\hline
\end{tabular}

The abrasive strength Improvement for variable watercement ratio are shown in Table 10.

Table 10. Rate of abrasion strength improvement with variable water-cement ratio

\begin{tabular}{|c|c|}
\hline $\begin{array}{c}\text { Percent of abrasion } \\
\text { strength improvement }\end{array}$ & W/C \\
\hline 39.51 & 0.35 \\
\hline 27.12 & 0.40 \\
\hline 13.41 & 0.45 \\
\hline 5.62 & 0.50 \\
\hline
\end{tabular}

Its water-cement ratio decreased from 0.55 to 0.35 the abrasion strength of concrete increased to $39.51 \%$. The water sand blast way is the suitable method for evaluating the abrasion strength of concrete against water, because this method can simulate the real abrasion added in concrete.

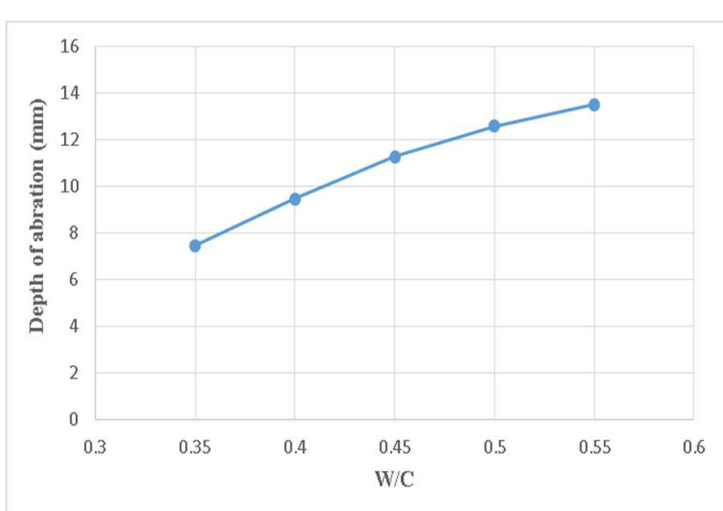

Figure 7. The fluctuation curve of abrasion depth with respect to water-cement ratio

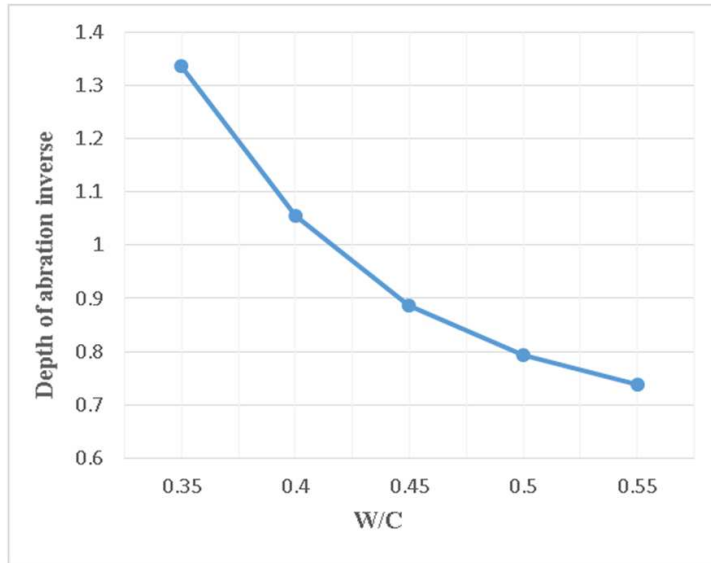

Figure 8 . The variation curve of abrasion resistance with respect to water-cement ratio

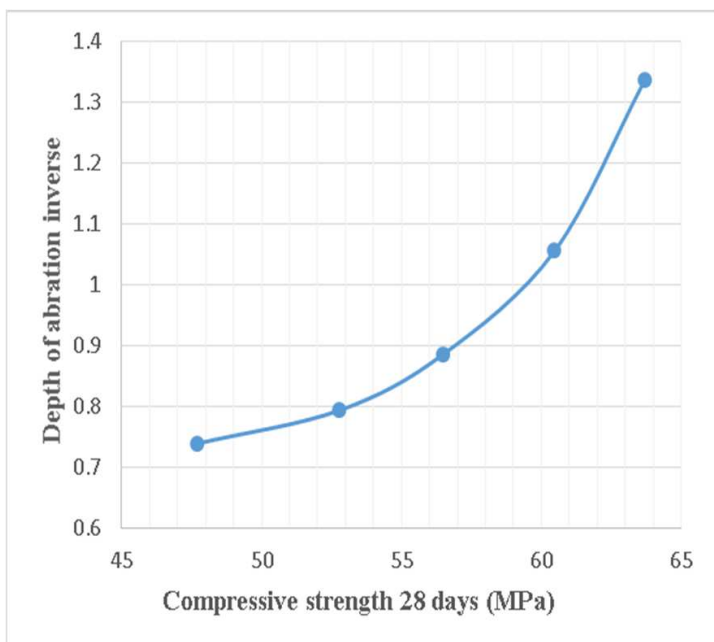

Figure 9. The variation curve of abrasion resistance with respect to compressive strength

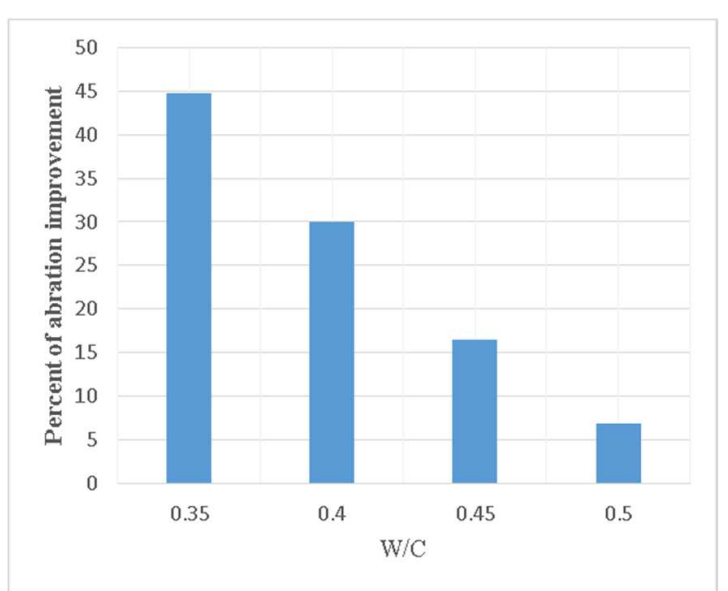

Figure 10. The chart of abrasion depth improvement with respect to water-cement ratio 
Figure 7 indicates the depth of abrasion according to watercement ratio. These figures show the barometer of abrasion depth against water-cement ratio. Regarding to these barometers and because of enhance of the water-cement ratio, the depth of abrasion increased. By increasing the water-cement ratio from 0.35 to 0.55 , the gradient of depth of abrasion curve will decrease gradually. This problem could be associated to two-phased nature of concrete in abrasion. The more water-cement ratio increases, the less the abrasion strength of mortar phase will be but the abrasion strength of concrete tends to be the same as the abrasion strength of aggregates. The concave of curve is on the bottom position and the curve within the water-cement ratio of 0.35 to 0.55 maximize. It seems that the maximum curve in accordance to water-cement ratio will be within 0.55 .

Since the abrasion strength of concrete is contradictorily related to depth of abrasion, the mentioned shapes can show the changes of abrasion strength curve. Regarding to these shapes, by increasing the water-cement ratio, the abrasion strength decreases (Fig. 8); by increasing the compressive strength of concrete, the abrasion strength increases, as well (Fig. 9).

Figure 10 reveals the percentage of abrasion strength improvement in relation to concrete with water-cement of 0.55 .

\subsection{Hydraulic conductivity coefficient and porosity experiments}

Developments and data for penetration depth for variable water-cement ratio are shown in Table 11.

Table 11. Rate for penetration depth with variable watercement ratio

\begin{tabular}{|c|c|}
\hline Penetration depth, $(\mathrm{mm})$ & W/C \\
\hline 0.784 & 0.35 \\
\hline 0.943 & 0.40 \\
\hline 1.391 & 0.45 \\
\hline 1.873 & 0.50 \\
\hline 2.756 & 0.55 \\
\hline
\end{tabular}

Table 12 indicates values of the hydraulic conductivity coefficient and porosity with regard to water-cement ratio.

Table 12. Hydraulic conductivity coefficient and porosity against water-cement ratio

\begin{tabular}{|c|c|c|}
\hline Porosity, (\%) & $\begin{array}{c}\text { Hydraulic conductivity, } \\
(\mathrm{m} / \mathrm{s})\end{array}$ & W/C \\
\hline 11.22 & $1.5 \times 10^{-15}$ & 0.35 \\
\hline 12.15 & $3.22 \times 10^{-15}$ & 0.40 \\
\hline 12.37 & $8.11 \times 10^{-15}$ & 0.45 \\
\hline 12.58 & $12.46 \times 10^{-15}$ & 0.50 \\
\hline 12.76 & $27.76 \times 10^{-15}$ & 0.55 \\
\hline
\end{tabular}

Figure 11 shows the water permeability depth according to various amounts of water-cement ratios.

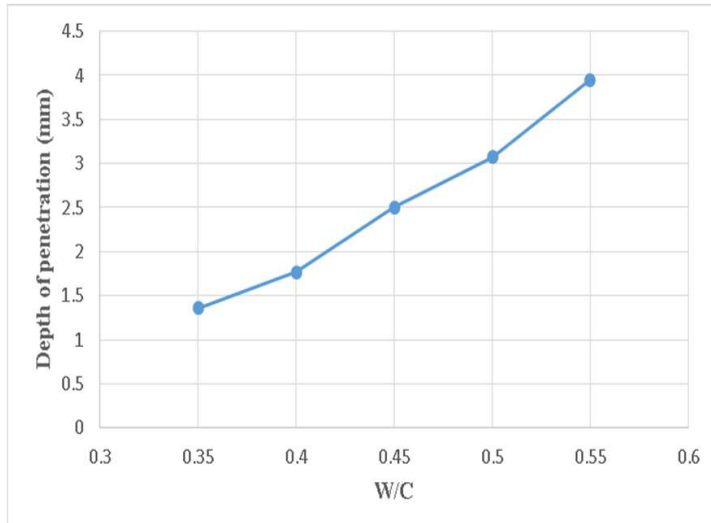

Figure 11. The fluctuation curve of penetration depth with respect to water-cement ratio

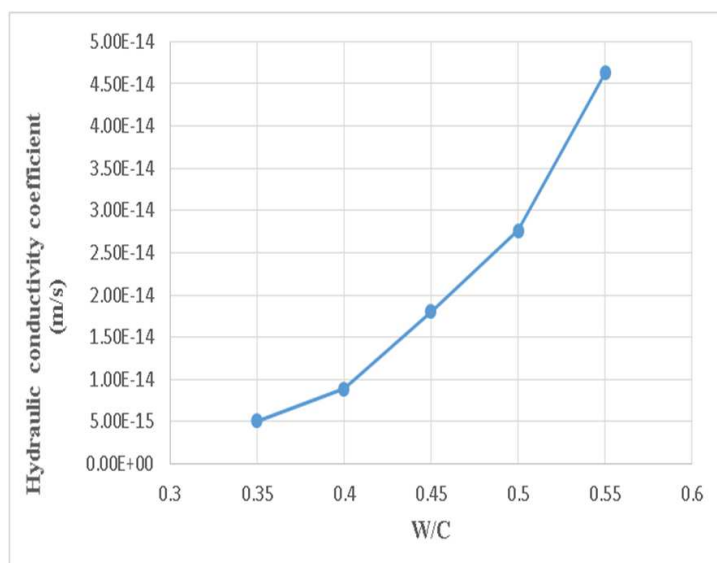

Figure 12. The variation curve of hydraulic conductivity coefficient with respect to water-cement ratio

Figure 12 reveals the amounts of the hydraulic conductivity coefficient of the concrete based on different amounts of water-cement ratios. Figure 13 indicates the curve changes for concrete porosity based on different amounts of watercement ratios.

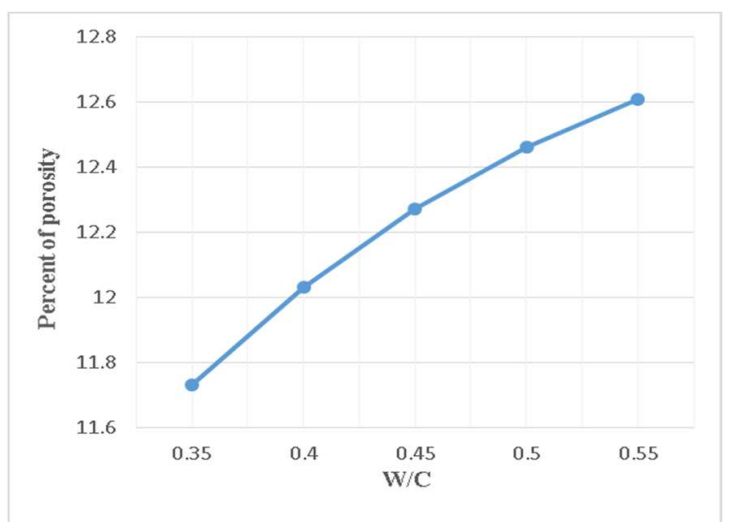

Figure 13. The fluctuation curve of concrete porosity with respect to water-cement ratio 


\section{CONCLUSIONS}

Considering the previous investigations and the tests of this research, the following results are obtained:

- The highest compressive strength after 7,28 and 90 days was like the samples with water-cement ratio of 0.35 and the least or minimum compressive strength after 7, 28 and 90 days was as the same of the strength of samples with water-cement ratio of 0.55 .

- By increasing water-cemnt ratio, the depth of abrasion increases and the abrasion resistance of the concrete decreases.

- Increasing the water-cement ratio from 0.35 to 0.55 , the gradient of depth of abrasion curve will reduce slowly. This problem is associated with two-phased nature of concrete in abrasion so that the more water-cement ratio increases, the less the abrasion strength of mortar phase will be but the abrasion strength of concrete tends to be the same as the abrasion strength of aggregates.

- To increase the abrasion strength of concrete, it is necessary to enhance the mortar phase and the aggregate phase with each other. Mortar phase can increase by education of water-cement ratio, using Nano-silica, and suitable curing; Moreover, aggregate phase can improve by abrasion-resistant aggregates such as granite aggregates.

- By increasing the compressive strength of concrete, the abrasion strength increases, as well.

- By increasing water-cement ratio, the hydraulic conductivity coefficient and porosity of concrete increases.

\section{References}

ASTM C 143-78, Standard Test Method for Slump Experiment of Concrete.

ASTM C 136, Standard specification for standard sand, Annual book of ASTM standards.

ASTM C 418, Standard Test Method for Abrasion Resistance of Concrete by Sandblasting.

ACI Committee 211. 2009, Standard Practice for Selecting Proportions for Normal, Heavyweight and Mass Concrete. American Concrete Institute, USA.

Ali, I., 2012, New generation adsorbents for water treatment, Chem Rev, 112:5073-5091.

Ahmad, S., Azad, A.K., Loughlin, K. F., 2005, A study of permeability and tortuosity of concrete, 30 th conference on our world in concrete and structures, 45:23-30.
Al-Amoudi, O.S.B., Maslehuddin, M., Lashari, A.N., Almusallam, A.A., 2003, Effectiveness of corrosion inhibitors in contaminated concrete, Cement and Concrete Composites, 25:439-449.

BS 1881: Part 116. 1983, Testing concrete: Method for determination of compressive strength of concrete cubes. British Standard Institution, London.

Benavente, D., Fort, R., Ordóñez, S., 2004, Durability estimation of porous building stones from pore structure and strength, Engineering Geology, 74(1):113-127.

Bentz, D.P., Stutzman, P.E., 2006, Curing hydration and microstructure of cement paste, ACI Materials Journal, 103(5):348-356.

Baradan, B., Yazici, H., 2002, Betonarme yapılarda kalıcılık (Durabilite), Izmir: Dokuz Eylu, 1 University Press.

ISO 1920-5 Testing of concrete Part 5: Properties of hardened concrete other than strength, Article 5 of this standard specifies the procedure for determination of the depth of penetration of water under pressure.

Ishida, T., Maekawa, K., Kishi, T., 2007, Enhanced modeling of moisture equilibrium and transport in cementitious materials under arbitrary temperature and relative humidity history, Cement and Concrete Research, 37(4): 565-578.

Kim, Y.Y., Lee, K.M., Bang, J.W., Kwon, S.J., 2014, Effect of w/c ratio on durability and porosity in cement mortar with constant cement amount, Advances in Materials Science and Engineering, Article ID 273460.

Lorenzo, M.P., Goni, S., Guerrero, A., 2003, Role of aluminous component of fly ash on the durability of Portland cement fly ash pastes in marine environment, Waste Management, 23: 785-792.

Mehta, P.K., Meryman, H., 2009, Tools for reducing carbon emissions due to cement consumption, Structure magazine, 21:11-15.

Olivier, J.G.J., Greet, J.M., Peters, J.A.H.W., 2012, Trends in global $\mathrm{CO}_{2}$ emissions 2012 report, PBL Netherlands Environmental Assessment Agency, 14:17-24.

Shannag, M.J., Shaia, H.A., 2003, Sulfate resistance of highperformance concrete, Cement and Concrete Composites, 25:363-369.

Wong, H.S., Buenfeld, N.R., 2009, Determining the watercement ratio, cement content, water content and degree of hydration of hardened cement paste: Method development and validation on paste samples, Cement and Concrete Research, 39(10):957-965.

Yigiter, H., Yazici, H., Aydın, S., 2007, Effects of cement type, water-cement ratio and cement content on sea water 
resistance of concrete, Building and Environment, 42:1770-

1776. 